\title{
Susceptibility Locus for IgA Deficiency and Common Variable Immunodeficiency in the HLA-DR3, -B8, -Al Haplotypes
}

\author{
Harry W. Schroeder, Jr., ${ }^{1,3,4}$ Zeng-Bian Zhu, ${ }^{2,3}$ Ruth E. March, ${ }^{8}$ \\ R. Duncan Campbell, ${ }^{8}$ Seth Mark Berney, ${ }^{2,3}$ \\ Sergei A. Nedospasov, ${ }^{9,10}$ Regina L. Turetskaya, ${ }^{9,10}$ \\ T. Prescott Atkinson, ${ }^{1,5}$ Rodney C. P. Go, ${ }^{6}$ Max D. Cooper, ${ }^{1,3,4,5,7}$ \\ and John E. Volanakis ${ }^{2,3}$
}

Divisions of ${ }^{1}$ Developmental and Clinical Immunology and ${ }^{2}$ Clinical Immunology and Rheumatology, Departments of ${ }^{3}$ Medicine, ${ }^{4}$ Microbiology, ${ }^{5}$ Pediatrics, and ${ }^{6}$ Public Health, and the ${ }^{7}$ Howard Hughes Medical Institute, University of Alabama at Birmingham, Birmingham, Alabama, U.S.A.

${ }^{8}$ MRC Immunochemistry Unit, Department of Biochemistry, University of Oxford, Oxford, U.K.

${ }^{9}$ Laboratory of Molecular Immunoregulation, DBS and Intramural

Research Support Program, SAIC Frederick, National Cancer Institute-Frederick Cancer Research and Development Center, Frederick, Maryland, U.S.A.

${ }^{10}$ Engelhardt Institute of Molecular Biology and Belozersky Institute of Physico-Chemical Biology, Moscow, Russia

Communicated by M. D. Cooper. Accepted December 8, 1997.

\begin{abstract}
Background: A common genetic basis for IgA deficiency (IgAD) and common variable immunodeficiency (CVID) is suggested by their occurrence in members of the same family and the similarity of the underlying B cell differentiation defects. An association between IgAD/CVID and HLA alleles DR3, B8, and Al has also been documented. In a search for the gene(s) in the major histocompatibility complex (MHC) that predispose to IgAD/CVID, we analyzed the extended MHC haplotypes present in a large family with 8 affected members. Materials and Methods: We examined the CVID proband, 72 immediate relatives, and 21 spouses, and determined their serum immunoglobulin concentrations. The MHC haplotype analysis of individual family members employed 21 allelic DNA and protein markers, including seven newly available microsatellite markers. Results: Forty-one (56\%) of the 73 relatives by com-
\end{abstract}

mon descent were heterozygous and nine (12\%) were homozygous for a fragment or the entire extended MHC haplotype designated haplotype 1 that included HLADR3, -C4A-0, -B8, and -Al. The remarkable prevalence of haplotype 1 was due in part to marital introduction into the family of 11 different copies of the haplotype, eight sharing 20 identical genotype markers between HLA-DR3 and HLA-B8, and three that contained fragments of haplotype 1 .

Conclusion: Crossover events within the MHC indicated a susceptibility locus for IgAD/CVID between the class III markers D821/D823 and HLA-B8, a region populated by 21 genes that include tumor necrosis factor alpha and lymphotoxins alpha and beta. Inheritance of at least this fragment of haplotype 1 appears to be necessary for the development of IgAD/CVID in this family. 


\section{Introduction}

Immunoglobulin (Ig)A deficiency (IgAD), the most frequently recognized primary immunodeficiency, occurs with an incidence of approximately 1 in every 600 individuals of European ancestry (reviewed in refs. 1 and 2). Common variable immunodeficiency (CVID) is the second most common type of primary immune deficiency in European populations $(2,3)$. B cells are present in both IgAD and CVID patients, but a variable differentiation defect is seen for plasma cells of the different isotypes $(2,4)$. Individuals with CVID are typically panhypogammaglobulinemic, although some produce substantial amounts of IgM, and individuals with IgAD may also be deficient in the IgG subclasses $\mathrm{IgG}_{2}$ and $\operatorname{IgG}_{4}(2,5,6)$. IgAD and CVID thus represent opposite poles of an immunodeficiency spectrum that ranges from selective IgAD to an inability to produce antibodies of any isotype.

IgAD may affect several members of the same family (7) and its incidence is highly variable in different population groups. The prevalence of IgAD among African-Americans is onetwentieth of that seen in European-Americans $(8,9)$, and the incidence appears even lower among Japanese (1 in 18,500) (10). Among Israeli army recruits, the prevalence of IgAD is related to ethnicity, with more recruits of European derivation affected than those of North African, Israeli, or Asian derivation (11). These differences suggest that genetic factors play a major role in the pathogenesis of IgAD, but the mode of familial transmission is unclear as some pedigrees suggest a pattern of autosomal dominance and others autosomal recessive inheritance $(7,12,13)$. Individuals with either IgAD or CVID can be seen in multiplex families (14). Coupled with the similarity in clinical phenotype, these observations support the hypothesis that IgAD and CVID reflect a common underlying genetic defect (15).

In an earlier study, we found that 24 of 31 IgAD and CVID patients in a clinic population, including all of the familial cases within this group, shared either complete copies or extended

The publisher or recipient acknowledges the right of the U.S. government to retain a non-exclusive, royalty-free license in and to any copyright covering the article.

Address correspondence and reprint requests to Dr. Harry W. Schroeder, Jr., Division of Developmental and Clinical Immunology, Wallace Tumor Institute 364, UAB Station, University of Alabama at Birmingham, Birmingham, Alabama 35294-3300, U.S.A. Phone: (205) 934-3370; Fax: (205) 934-1875; E-mail: Harry.Schroeder@ccc.uab.edu fragments of two major histocompatibility complex (MHC) haplotypes designated haplotype 1 (HLA-DQB 1 0201, HLA-DR3, C4B-Sf, C4A-0, G11-15, Bf-0.4, C2-a, HSP-7.5, TNF-5, HLA-B8, HLA-Al) and haplotype 2 (HLA-DQBl 0201, HLA-DR-7, C4B-S, C4A-L, G11-4.5, Bf-0.6, C2-b, HSP-9, TNF-9, HLA-B44, HLA-A29) (16). These observations confirmed many previous reports of the association of IgAD with HLA-Al, -B8, -DR3, and -C4A-0 (16-23) and supported the hypothesis of a similar genetic basis for IgAD and CVID. A detailed analysis of the MHC haplotypes in the 31 immunodeficient patients that belonged to 21 different families suggested the existence of a susceptibility gene or genes for both CVID and IgAD within the class III region of the MHC in linkage disequilibrium with class I and/or class II alleles (16). Seventy genes have been mapped within the $1,100 \mathrm{~kb}$ of DNA that separates HLA-DR from HLA-B (24). Many of these class III region genes are expressed by cells of the lymphoid, myeloid, and monocyte lineages and have either a demonstrated or potential role in innate or adaptive immune responses. Although informative de novo crossovers of the MHC haplotypes were not observed within kindreds in the previous study, 2 of the $14 \mathrm{immu}$ nodeficient individuals with haplotype 1 inherited only fragments of the haplotype (16). At the telomeric class I terminus of the haplotype, both MHC alleles retained the TNF-5 RFLP marker, but one fragment lacked the HLA-Al allele and the second lacked both HLA-Al and HLA-B8. At the centromeric class II terminus of their fragments of haplotype 1, both patients exhibited the C4A-0 gene deletion, but they lacked HLA-DR3. These findings implicated the class III region of haplotype 1 as the locus conferring susceptibility for development of the immunodeficiencies seen in patients with IgAD and CVID.

A major confounding factor in the analysis of clinic populations is the potential for genetic heterogeneity. Analysis of individual families, especially large families, decreases the likelihood of genetic heterogeneity. Of the 5 multiplex families identified among the original 21 kindreds that we studied (16), the S12 family (referred to as the F12 family in ref. 16) proved to be of particular interest. The CVID proband had inherited a complete copy of haplotype 1 . The eldest of the proband's 3 children and a nephew were also IgA-deficient and carried a complete copy of haplotype 1 . Both of these relatives inherited haplotype 1 from their unaffected mothers, neither of whom were blood relatives of the proband. The 
youngest child of the proband inherited haplotype 1 from his father, but had normal serum immunoglobulin concentrations when first evaluated. Over a 12-year period, however, changes in serum immunoglobulin concentrations occurred in two of the proband's children. The eldest son progressed from IgAD to CVID, and the youngest son acquired selective IgA deficiency, then progressed to IgAD with $\operatorname{IgG}_{2}$ subclass deficiencies (25) and, most recently, to CVID.

To refine the definition of the haplotype 1 gene(s) predisposing to the development of IgAD and CVID, we have extended our study to include additional members of the $S 12$ family and a more extensive analysis of their MHC haplotypes. The MHC haplotypes of 73 family members were classified initially by analysis of polymorphic markers for four of the class III region genes (16) or their protein products (26), and then by analysis of the tumor necrosis factor (TNF)-associated DNA markers a and b (27). Additional DNA markers spanning the MHC locus $(15,16,28)$ were also assessed in immunodeficient family members. The data obtained indicate a more precise localization of the susceptibility locus within the class III region of haplotype 1 .

\section{Identification of the Family, Materials, and Methods}

The Family

The proband (S12.II.11), a 31-year-old white male, presented to the University of Alabama at Birmingham (UAB) Immunodeficiency Clinic in 1980 with a panhypogamma-globulinemia and a 16-year history of recurrent sinopulmonary infections. A nephew with IgAD (S12.III.9), a son with IgA and IgG subclass deficiencies (S12.III.28), and a son with CVID (S12.III.26) were previously reported $(16,25)$. During the course of this extended analysis, 84 relatives with a common ancestry and 33 spouses were identified (Fig. 1). Seventy-three of the relatives and 21 of the spouses were examined. The research protocol of the study of this rural Alabama family was approved by the UAB Human Use Institutional Review Board.

\section{Serum Immunoglobulin Measurements}

Serum immunoglobulin concentrations were determined by nephelometry using the QM300 protein analysis system. Coefficients of variation calculated from replicates of three samples run in each of 10 separate assays were: 3.4 to $5.0 \%$ for serum IgG, 3.5 to $5.3 \%$ for serum IgA, and 4.1 to $6.3 \%$ for serum IgM (Sanofi Diagnostics Pasteur, Inc., Chaska, MN). Normal laboratory ranges for IgM, IgG, and IgA are 45-226 mg/dl, 775-1850 $\mathrm{mg} / \mathrm{dl}$, and $60-375 \mathrm{mg} / \mathrm{dl}$, respectively. IgA deficiency was defined by serum IgA concentrations below the limits detectable by nephelometry $(\leq 8 \mathrm{mg} / \mathrm{dl})$. Partial IgA deficiency was defined by serum IgA immunoglobulin concentrations that were less than two standard deviations below the mean for the age group.

\section{MHC Haplotyping}

The MHC haplotype analysis of individual family members employed 21 individual polymorphic DNA and protein markers. Each family member underwent initial restriction fragment length polymorphism (RFLP) analysis of C4-A, C4-B, and $\mathrm{C} 2$, as well as polymerase chain reaction (PCR) analysis of a MspI polymorphism of factor $\mathrm{B}(B f)$ as described previously (16). Phenotyping of $\mathrm{C} 4-\mathrm{A}$ and $\mathrm{C} 4-\mathrm{B}$ protein products was performed on frozen plasma samples by using previously described methods (26). In selected relatives, a 328 base pair (bp) fragment upstream of TNF- $\alpha$ containing the $5^{\prime}$ promoter region was amplified and sequenced by PCR (29) on an ABI 377 Automated Sequencer (Applied Biosystems, Foster City, CA). The TNF locus was analyzed with the TNF-associated DNA microsatellite markers $a$ and $b$ that measure repeat sequences adjacent to the LTA gene. These were genotyped by PCR as previously described $(27,30)$. In some relatives, the protein products of HLA-A and -B alleles were typed by the microdroplet lymphocytotoxicity assay (15), and in others they were DNA typed by the sequence-specific primer amplification method using a Pel-Freez Class I ABC SSP Unitray (Pel-Freez, Brown Deer, WI). The identity of the protein product of the HLA-DR allele was assessed in some family members by the microdroplet lymphocytotoxicity assay (15) and confirmed in others by PCR amplification of a highly polymorphic region of the DRB locus from genomic DNA, followed by blotting and hybridization of sequence-specific radiolabeled oligonucleotide probe specific for the DR3 and DR7 alleles associated with haplotype 1 and 2 (16). For relatives with representative copies of haplotype 1 who differed by descent, microsatellite DNA marker analysis was performed on the 


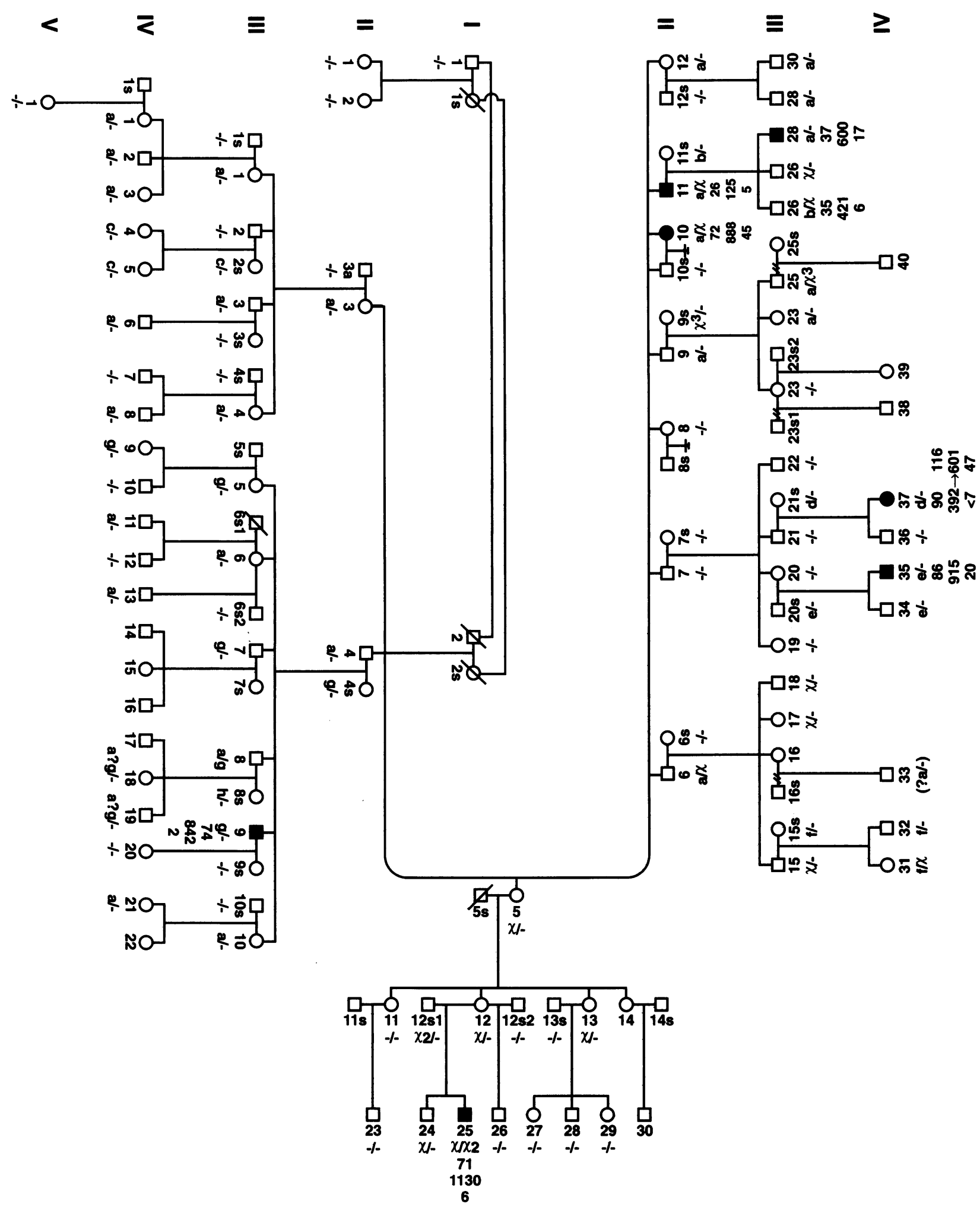

Fig. 1. Pedigree of family S12. Affected family members are identified by solid squares or circles. Each individual is identified by generation (I-V), consecutively within each generation (e.g., generation II.1-12), and by an " $\mathrm{s}$ " if a spouse. The MHC haplotype of the individual is shown underneath his or her pedigree symbol. Complete copies of haplotype $l$ are identified as "a" through " $h$ ", and the three different fragments as $\chi, \chi^{2}$, and $\chi^{3}$. Haplo- types other than copies of haplotype 1 are designated by a dash. In S12.IV.18 and S12.IV.19, we cannot determine whether the a or $\mathrm{g}$ copy of haplotype 1 was inherited from their father, S12.III.8, hence the "a?g" haplotype designation. For immunodeficient individuals, serum immunoglobulin concentrations in $\mathrm{mg} / \mathrm{dl}$ are shown in the order IgM, IgG, and IgA. 


\section{Centromere}

Telomere $\rightarrow$

A

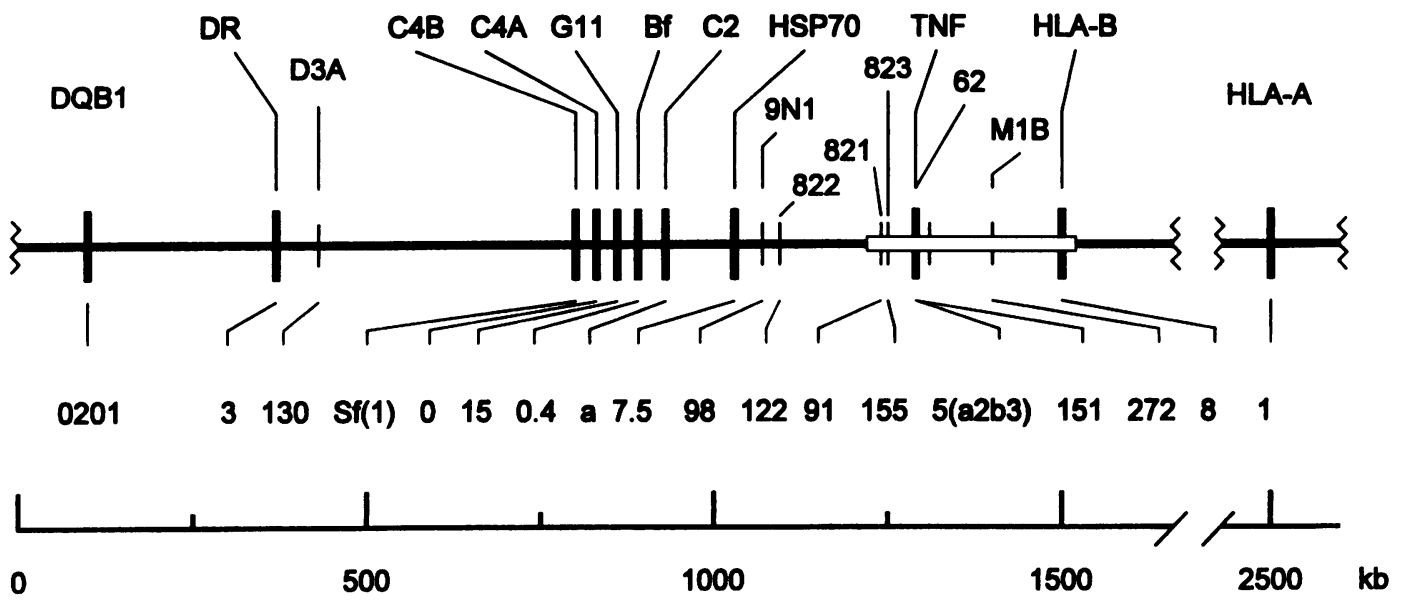

B

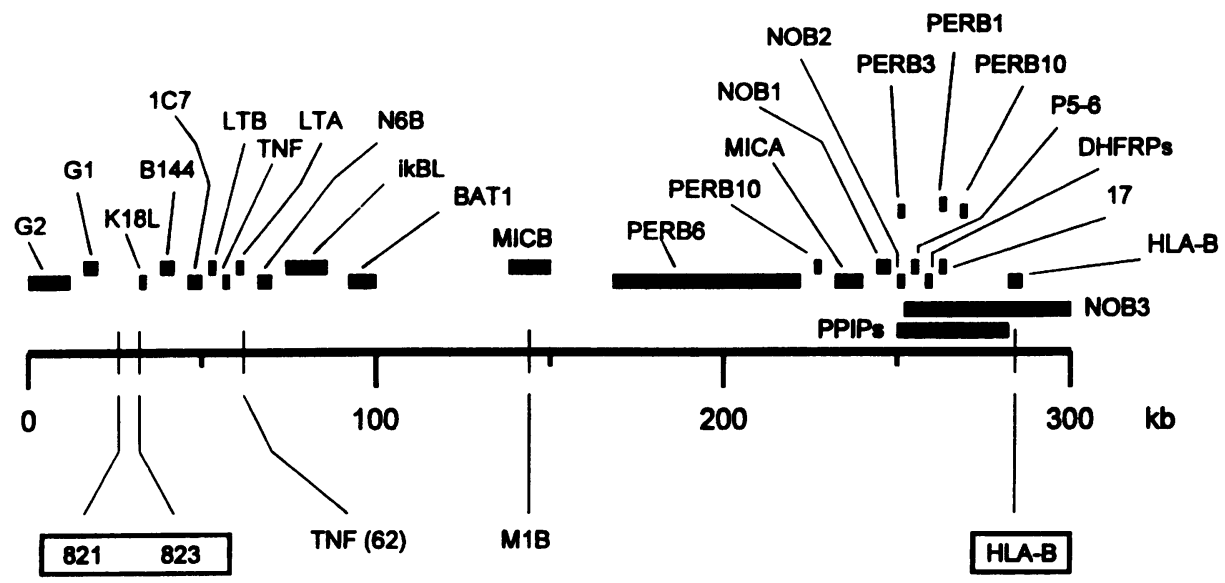

Fig. 2. DNA marker analysis of selected loci across class I, II, and III regions. (A) Map of the MHC locus on chromosome six showing the relative position of selected class I, II, and III genes as well as the approximate location of 11 markers used to identify haplotype 1. A susceptibility locus for IgAD/ CVID appears to lie within the interval illustrated by

D3A, 9N11, 822, 821, 823, 62, and M1B loci that are distributed across the class III region (28) (Fig. 2). These microsatellite markers were fluorescently labeled and detected on an ABI 377 sequencer (Applied Biosystems, Foster City, CA).

\section{Statistical Analysis}

Differences in the frequency of study parameters between two populations were assessed by Student's $t$ test, two-tailed, or by binomial probability, one-tailed, when indicated. the open bar, which is delimited by microsatellite markers $821 / 823$ towards the class II terminus and HLA-B at the class I terminus of the region. (B) An expanded view of the susceptibility locus illustrated in the open bar above and the genes that have been mapped to this interval (24).

\section{Results}

More than $90 \%$ of the members of the S12 family (Fig. 1) live within 25 miles of each other in southwestern Alabama. The parents (S12.I.3 and S12.I.4) of the proband are deceased. In 1995 , their descendents numbered 10 children, 30 grandchildren, 40 great grandchildren, and 1 great great grandchild. The proband's paternal uncle (S12.I.1) and maternal aunt (S12.I.2) married and had 2 daughters (S12.II.1 and S12.II.2). Including the proband, 72 relatives by common 
descent ( $84 \%$ ascertainment) and 13 spouses underwent determination of serum IgM, IgA, and IgG concentrations and analysis of their MHC polymorphisms. Eight of these were immunodeficient: three with CVID (the proband S12.II.11, and his sons S12.III.26 and S12.III.28), three with complete IgA deficiency (S12.III.9, S12.IV.25, and S12.IV.37), and two with partial IgA deficiency (S12.II.10 and S12.IV.35). None of the 13 spouses tested had serum antibody deficits. Of the remaining family members, 1 relative by common descent and 8 spouses underwent MHC polymorphism analysis alone, 2 relatives by common descent and 2 spouses were deceased, and 9 relatives by common descent and 10 spouses declined evaluation.

Of the 8 immunodeficient members identified in this family, seven were found to have a complete set of the markers that identify haplotype 1 including the complotype markers C4BSf, C4A-0, Bf-0.4, and C2-a, as well as HLA-DR3 and HLA-B8 (16). Only 2 of these individuals inherited haplotype 1 from a common ancestor (S12.II.11 and S12.III.28). We termed MHC haplotypes that shared identity in all markers between HLA DR3 and B8, but which were derived from unrelated ancestors, "complete" copies of haplotype 1 . These were numbered alphabetically $a$ through $h$. Surprisingly, the eighth immunodeficient relative, S12.IV.25, who had undetectable levels of serum IgA on three separate occasions, was homozygous for HLA-DR4 and lacked the complotype markers associated with haplotype 1. Analysis of his TNF, HLA-B, and HLA-A loci indicated that this individual was homozygous for TNF-a2b3, HLA-B8, and HLA$A 1$, all of which are found in haplotype 1. Thus, the patient inherited two incomplete copies, or fragments, of haplotype 1 that retained the markers for TNF and HLA-B at the telomeric end of the haplotype. Neither of these proved to be de novo recombinants. One fragment, designated $\chi$, was inherited from the mother. This fragment was also present in 13 additional family members (Fig. 1). The second fragment, designated $\chi^{2}$, was inherited from the father.

Seven recently described microsatellite markers that span the HLA class III region (28) were used to clarify the relationship between the various copies of haplotype 1 that were derived from unrelated ancestors. All but one of the haplotype 1 copies that shared identical complotypes proved to have identical genotypic markers in the region spanning HLA-DR through HLA-A and thus share identity for the entire class III region (Table 1). The exception, fragment $\chi^{3}$, lacks HLA-DR3 but shares identity for the microsatellite marker D3A that is positioned between HLA-DR and C4B. Fragment $\chi$ shares identity with haplotype I for HLA-A through the microsatellite marker 823 , which is located between the Gl and B144 genes. Fragment $\chi^{2}$ shares extensive identity with haplotype 1 between the factor B locus and HLA-A. Within this fragment of the haplotype there are two polymorphic markers that differ between haplotype 1 and $\chi^{2}$. Haplotype 1 contains a 91 allele at microsatellite marker 821 (which is adjacent to the Gl gene) and a 272 allele at the M1B microsatellite marker (which is contained within the MICB gene), whereas fragment $\chi^{2}$ has the 93 and 276 alleles, respectively (Fig. 2, Table 1). These differences are most likely due to further expansion of the dinucleotide repeats that characterize the markers and suggest that the event that led to the creation of fragment $\chi^{2}$ is an ancient one.

The TNF- $\alpha$ allele of the DR3-B8-Al haplotype, our haplotype 1 , contains a polymorphic DNA sequence in the $5^{\prime}$ promoter region of the gene: the rare substitution of an adenine (TNF$308 \mathrm{~A}$ ) for guanine at position -308 in the presence of the common guanine at position -238 (TNF-238G) (31). Cells that contain the TNF308A mutation express more TNF- $\alpha$ than those with the common TNF-308G allele $(31,32)$. Given the lack of identity between fragment $\chi^{2}$ and haplotype 1 at the microsatellite markers 821 and MlB, we sought to further clarify the identity of the incomplete haplotype 1 in the TNF region by examination of this region of the TNF gene at the sequence level. A 328 bp fragment containing this region of the TNF- $\alpha$ gene from IgA-deficient individual IV.25 (genotype $\chi^{\prime} \chi^{2}$ ) and the CVID proband II.l l (genotype a/ $\chi$ ) was PCR amplified and directly sequenced from each patient. The patients proved homozygous for both the TNF-308A and TNF-238G alleles, indicating that the $\chi$ and $\chi^{2}$ fragments share identity with haplotype 1 for these TNF- $\alpha$ markers.

\section{Immunodeficiency Was Found Only in Individuals Having the G1-HLA-A Portion of Haplotype 1}

Of the 73 family members who share descent from a common ancestor (Fig. 1), 33 have one complete copy of haplotype 1 from the region between HLA-DR3 and C4A through HLA-A (Fig. 2). Of these, four are immunodeficient $(12 \%)$. Two individuals who are homozygous for complete copies of haplotype 1 have normal se- 


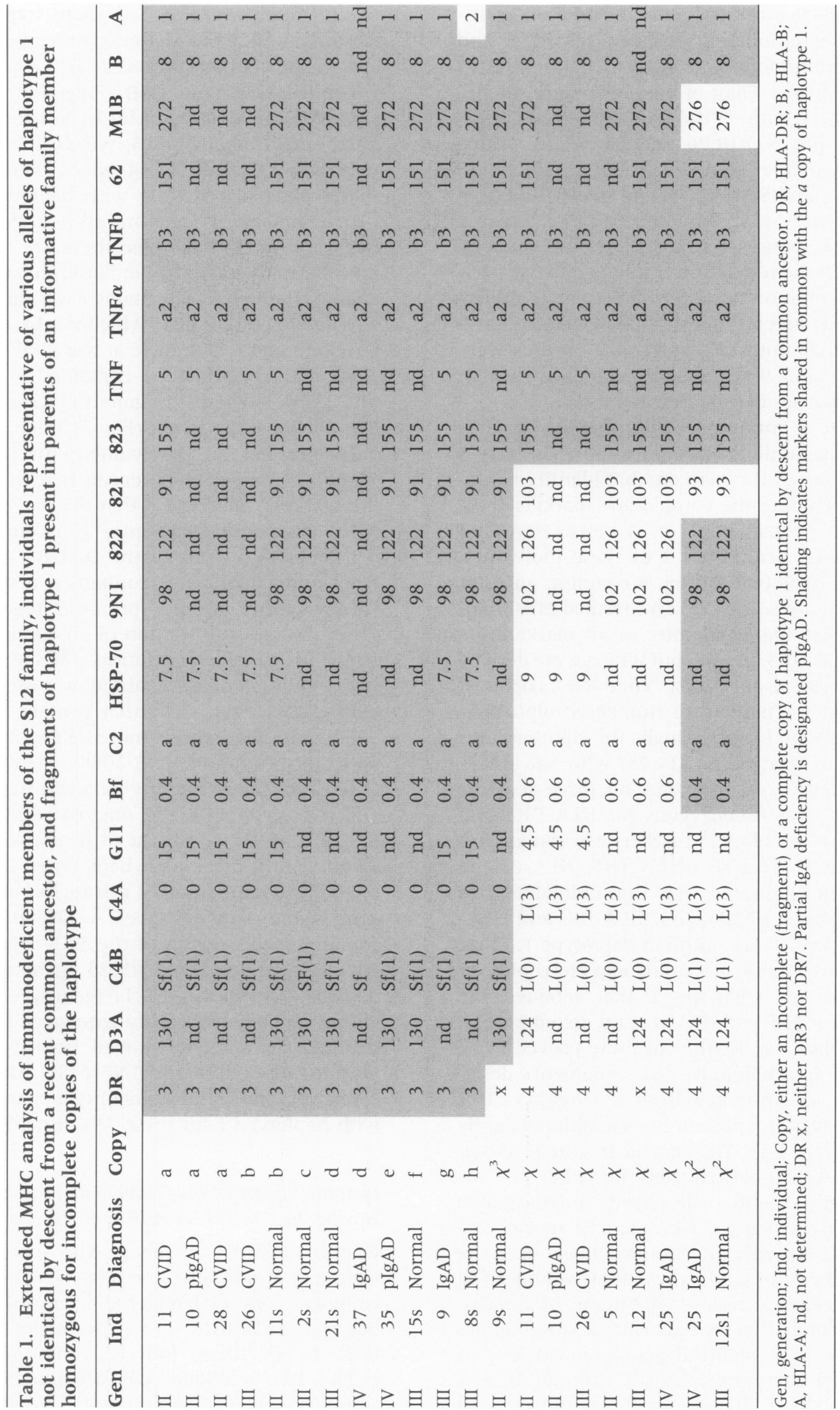


rum immunoglobulin concentrations. There are 8 family members with only a single copy of the $\chi$ fragment, all of whom have normal serum immunoglobulin concentrations. There are 6 individuals who are doubly heterozygous for a complete copy of haplotype 1 and the $\chi$ fragment, and are thus homozygous for the region delimited by the microsatellite markers $821 / 823$ at the centromeric class II terminus and HLA-Al at the telomeric class I terminus (we will henceforth refer to this region as 821/823:HLA-Al). Of these, three are immunodeficient $(50 \%)$. Finally, the IgA-deficient family member S12.IV.25 is doubly heterozygous for the two recombinant fragments, one of which contains the 821/823: HLA-Al portion of haplotype 1 , and the other has extended, but interrupted, identity from the factor B gene $(B f)$ through the telomeric class I terminus.

As a group, 50 relatives by common descent inherited at least a portion of haplotype 1. Eight of these are immunodeficient $(16 \%)$, whereas among the 22 relatives by common descent who have not inherited either a complete copy or a fragment of haplotype 1, none are immunodeficient $(p<0.05$, Student's $t$ test, two-tailed). The combined results of three previous studies indicated a $13 \%$ incidence of immunodeficiency (7 of 54) in individuals randomly selected for homozygosity for haplotype $1(16,17,33)$. In this family, the risk of immunodeficiency for relatives by common descent who are heterozygous for a complete copy of haplotype 1 (4 of 33 , or $12 \%$ ) is not statistically different from the general risk in the population for those homozygous for complete copies of haplotype $1(13 \%)(p=0.91$, Student's $t$ test, two-tailed). The risk in the family for individuals heterozygous for either a complete copy or the fragment of haplotype 1 proximal to 821/823:HLA-Al is also similar (4 of 41 , or $10 \%)(p=0.63$, Student's $t$ test, two-tailed). However, the risk of immunodeficiency for relatives by common descent who are homozygous for the 821/823:HLA-Al region of haplotype 1 ( 4 of 9 , or $44 \%$ ) is significantly greater than the risk for relatives by common descent who are heterozygous for either a fragment or a complete copy of haplotype $1(10 \%)(p=0.03$, Student's $t$ test, two-tailed), as well as for those in the general population who are homozygous for complete copies of haplotype $1(13 \%)(p=0.02$, Student's $t$ test, two-tailed). The higher risk for individuals homozygous for the region between 821/823 and HLA-A1 indicates that the centromeric terminus (towards class $\mathrm{II}$ ) of the IgAD/
CVID susceptibility locus lies between the 821 and 823 markers located between the Gl and B144 genes in the class III region of haplotype 1 .

The higher-than-expected prevalence of haplotype 1 in this family led us to investigate the pattern of parental transmission. The parents of proband S12.II.11 are deceased and the paternal uncle did not share a complete haplotype with the proband or his siblings, thus we were unable to assign parental transmission for generation II. However, including spouses, there were 11 mothers with one complete copy of haplotype 1 who married men without a complete copy of haplotype 1 . Of the 23 children tested, 17 inherited and 6 did not inherit haplotype 1 ( $p=0.03$, binomial probability, two-tailed). There were 3 mothers with complete copies of haplotype 1 whose husbands also had a complete copy of haplotype 1 . Of the 11 children tested, $10(91 \%)$ inherited at least one copy of haplotype 1. Although the percentage is high, the number of children was insufficient to reach statistical significance. Fragment $\chi^{3}$ lacks HLA-DR3 but shares identity with other copies of haplotype 1 in the remaining class III and class I markers. Of the 3 children of the mother with fragment $\chi^{3}$, one inherited the copy and two did not. However, her husband also has a complete copy of haplotype 1 , and two of her children inherited the full copy. There were 5 mothers with a copy of the $\chi$ fragment. Of their 8 children, four inherited the $\chi$ fragment and four did not. There are 4 fathers with one complete copy of haplotype 1 alone who married women without a complete copy of haplotype 1. Of their 7 offspring, five inherited a paternal copy of haplotype 1 and two did not ( $p=0.17$, binomial probability, two-tailed). An apparent bias in maternal or paternal transmission of haplotype 1 has been noted previously by a number of investigators (34-38); however, in other studies transmission of haplotype 1 has been stochastic $(39-41)$.

\section{Development of Normal Serum IgA Concentrations in an IgA-Deficient Infant with Haplotype 1}

In previous studies, we have documented improvement in serum immunoglobulin concentrations in patients with haplotype 2 , but not haplotype 1 (25). When first examined at age 12 months, S12.IV.37 had an undetectable serum concentration of IgA (normal for age, $20-60 \mathrm{mg}$ / dl). When re-examined at age 3 years and 4 months, S12.IV.37 had an IgA serum concentration of $47 \mathrm{mg} / \mathrm{dl}$, thus indicating that develop- 
ment of the capacity to produce IgA antibodies can be delayed in an individual with haplotype 1 .

\section{Discussion}

Antibody deficiencies are rarely absolute in CVID and IgAD patients who manifest a spectrum of immunodeficiencies that ranges from panhypogammaglobulinemia to complete IgA and IgG deficiency, to IgA deficiency with $\operatorname{IgG}_{2,4}$ subclass deficits to IgA deficiency, and to partial IgA deficiency $(42,43)$. Most affected individuals continue to produce detectable quantities of the deficient antibody isotypes, and the manifestations of immunodeficiency may change with time in an individual patient. In the S12 family, we observed progression from selective IgA deficiency to CVID over a 12-year period in a young adult (S12.III.26, ref. 25), progression from normal immunoglobulin concentrations to partial IgA deficiency to IgA deficiency with IgG subclass deficiencies to CVID over a 14-year period in a youth (S12.III.28, ref. 25 and this report), and improvement from IgA deficiency to normal IgA serum concentrations over a 2-year period in a young infant (S12.IV.37, this report). The variation in clinical phenotype raises the possibility that IgAD/CVID reflects quantitative and potentially reversible changes in lymphocyte function. The fluctuations that may occur in immunoglobulin serum concentrations also complicate the genetic analysis of these disorders.

Previous studies of the genetics of IgAD and CVID have suggested an autosomal recessive pattern of inheritance in some families, and autosomal dominant transmission in others $(7,12,13,44)$. Several studies have now documented a higher-than-expected prevalence of haplotype 1 in IgAD/CVID patients (15-23,25). When individuals selected on the basis of homozygosity for haplotype 1 were evaluated, $13 \%$ (7 of 54) proved to be IgA-deficient compared with the estimated prevalence of $0.17 \%$, approximately a 75 -fold increase $(16,17,33)$. Cosegregation of immunodeficiency and a large panel of MHC genetic markers indicate that all of the immunodeficient individuals in the $\mathrm{S} 12$ family share at a minimum a common fragment of haplotype 1. Conversely, Vorechovsky et al. (45) failed to demonstrate close linkage between the MHC region and inheritance of IgAD and CVID using an autosomal inheritance model with incomplete penetrance and phenocopies, and sibpair analysis. Several differences in study design may contribute to differences in the conclusions reached in these studies. Whereas the Vorechovsky studies involved two- and three-generation families from several European communities, the present study was of a single large family, thereby reducing the risk of genetic heterogeneity that may complicate linkage analysis. In our pedigree, a much higher risk was observed for individuals homozygous for the susceptibility locus within haplotype 1 than for individuals who are heterozygous. This suggests that the autosomal dominant model may not apply here, and misspecification of the transmission model would tend to inflate the recombination fraction in a linkage analysis (46). The genetic markers employed in the present study were designed to cover the entire MHC region, and the use of these markers was essential for the identification of the immunodeficiency phenotype association with genes in a subregion of the MHC class III region. By comparison, only two of the genetic markers employed in the Vorechovsky study were located within the MHC region-the DQ $\beta 57$ codon marker and the D6S273 microsatellite, the latter being closest to our microsatellite 822. Significantly, both of these markers lie outside the candidate area identified in the present study.

A central tenet of the existence of ancestral or extended haplotypes holds that any locus within a particular ancestral haplotype should have identity in genetic content with similar ancestral haplotypes from individuals who are not obviously related by common descent from a recent ancestor (47). By extension, fragments of the ancestral haplotype would also be expected to share genetic content in the region bounded by that fragment. In the S12 family, different copies and even fragments of haplotype 1 appear interchangeable in enhancing the risk for IgAD/ CVID. The interchangeability of the different copies of haplotype 1 in this family implies that the mutation that permits development of immunodeficiency is an ancient one and does not reflect recent alteration of a gene that influences lymphocyte function. Since all individuals with the HLA-DR3, -B8, -Al haplotype carry an enhanced risk for the development of immunodeficiency, haplotype 1 meets the definition of a susceptibility locus, i.e., encoding a gene or genes that increase susceptibility for the development of disease rather than causing the disorder directly (48).

Through analysis of the fragments of haplotype 1 in affected individuals it is possible to 
define the susceptibility locus more precisely. In a previous study (16), we identified two patients with CVID who shared all seven polymorphic markers tested in the class III region, including C4B and TNF, but lacked several of the class I and class II alleles characteristic of haplotype 1. One individual had HLA-B8, but lacked HLA-DR3 and HLA-Al. The second had an even smaller fragment of haplotype 1 and lacked not only HLA-DR 3 and HLA-A1 but also HLA-B8. This suggested that the boundaries for the susceptibility locus for haplotype 1 lay between TNF and HLA-B on the telomeric class I end of the MHC, and between $\mathrm{C} 4 \mathrm{~B}$ and DR on the centromeric class II end. Other studies suggested an IgAD/ CVID association with class II MHC genes, specifically HLA-DQB1 $(18,23)$. However, a recent study of Sardinians homozygous for a crossover HLA-DR3 haplotype yielded evidence against an IgAD/CVID susceptibility locus within the class II region (49). The Sardinian and North European HLA-DR3 haplotypes share the same HLADRB I, DQAl, and DQB I alleles, but they differ in the class III and I regions starting from the HLA-DRB3 locus apparently because of an ancestral crossover event. Both haplotypes have class II susceptibility genes for insulin-dependent diabetes mellitus (IDDM) and celiac disease (50), but analysis of 43 individuals homozygous for this Sardinian haplotype failed to identify any with IgAD/CVID. In our family study, the high prevalence of immunodeficiency among individuals homozygous for fragments of haplotype 1 bounded by the microsatellite markers $821 / 823$ and HLA-Al, and IgAD in a family member who lacks the class II region of haplotype 1, further excludes class II genes as susceptibility loci for IgAD/CVID. Our previous study (16) placed the telomeric boundary of the haplotype 1 susceptibility locus between TNF and HLA-B and the centromeric boundary between C4B and HLADR. The analysis of this family moves the centromeric boundary of the class III susceptibility locus $800 \mathrm{~kb}$ towards the telomeric class I region, thus reducing the number of potential candidate genes in haplotype 1 by more than two-thirds.

Twenty-one genes with open reading frames have been identified in the 300 kilobases of DNA that separate 821/823 from HLA-B (Fig. 2; reviewed in ref. 24). Minimal information is available for 4 of these genes (NOB 1, NOB 2, NOB 3, and DHFPRPs). There are 4 class I-like genes (MIC B, MIC A, PERB 3, and HLA 17). There are two copies of a gene that shares homology to CD75 (PERB 10), as well as a gene expressed in liver that can cross-hybridize at low stringency to the gene for CD40 ligand (PERB 6). Three genes (I $\kappa \mathrm{BL}, \mathrm{BAT} 1$, and PERB 1) are involved in general cell growth and development. I $\kappa \mathrm{BL}$ shares extensive sequence homology with the p100 $\mathrm{NF} \kappa \mathrm{B}$ variant and contains 2 potential casein kinase II and 5 potential protein kinase $C$ phosphorylation sites as well as a leucine zipper-like domain at the C-terminus. The product of this gene may be involved in regulation of the expression of many cytokine genes, including the TNF/lymphotoxin (LT) genes. BAT 1 is a member of the DEAD family of ATP-dependent RNA helicases which participate in initiation of translation, RNA splicing, ribosome assembly, and cell growth and division. PERB $l$ is a polymorphicreceptor, tyrosine kinase-designated fibroblast growth factor receptor 6 (FGFR6). Its murine homologue is expressed in testis and possibly in spleen, kidney, and brain. Three genes (B144, IC7, and NB6) are expressed in lymphoid tissues, and 1 gene (P5-6, also designated PERB7) belongs to the $\mathrm{P} 5$ family of genes often located near class I genes and transcribed primarily in lymphoid cells. The B144 gene, also known as leukocyte-specific transcript 1 (LST1), is an interferon (IFN)-inducible $800 \mathrm{bp}$ transcript found in $\mathrm{B}$ and $\mathrm{T}$ lymphocytes, macrophages, and histiocytes. The 1C7 locus has been identified as the source of an RNA transcript expressed in spleen. The NB6 locus is the source of an RNA transcript isolated from an Epstein-Barr virus (EBV) lymphoblastoid cell line. Both 1 C7 and NB6 share minimal DNA or peptide homology with known genes. Whether any of these 18 genes participate in the regulation of the immune response is currently unknown.

The 3 remaining genes in this $\mathrm{MHC}$ region deserve special consideration. TNF- $\alpha$, lymphotoxin a (LT- $\alpha$, also called TNF- $\beta$ ), and LT- $\beta$ are members of the tumor necrosis factor (TNF) superfamily and all are critically involved in the regulation of infectious, inflammatory, and autoimmune phenomena (reviewed in refs. 51,52). TNF- $\alpha$ is produced by macrophages, mast cells, natural killer (NK) cells, B cells, and T cells in response to various stimuli. It exists both as a transmembrane protein and as a homotrimeric secreted molecule. TNF- $\alpha$ can both enhance and inhibit IFN- $\gamma$-induced MHC class II expression in a variety of cell types (53). These opposing effects depend on the maturation and differentiation stages of the cell. LT- $\alpha$, a major product of activated lymphocytes, exists as either a secreted homotrimeric molecule or a cellular membrane 
protein when complexed with LT- $\beta$, a type II transmembrane protein (54). The LT- $\alpha \beta$ complex on activated lymphocytes signals exclusively through interaction with the LT- $\beta$ receptor (55), while TNF- $\alpha$ and soluble LT- $\alpha$ share the same cell surface receptors, TNFRI (p55/CD120a) and TNRII (p75, CD120b) (52).

Mice rendered deficient in LT- $\alpha$ or LT- $\beta$ have defective development of lymph nodes and Peyer's patches, as do mice in which the function of the cell surface LT- $\alpha / \beta$ complex has been blocked $(56-60)$. LT- $\alpha$ and LT- $\beta$ knock-out mice have normal serum IgM concentrations but are IgAdeficient $(58,59)$. LT- $\alpha$ knock-out mice also demonstrate an inability to produce antigen-specific IgG in either primary or secondary responses (61). TNF- $\alpha$ knock-out mice lack splenic primary B cell follicles and germinal centers $(58,62)$. The serum IgA profile has not been reported in these mice, but IgG antibody immune responses are impaired. Exposure to LT- $\beta$-Ig fusion proteins, but not TNFR-Ig, disrupts the normal development of lymphoid tissue architecture, thus indicating a requirement of the interaction between the surface LT- $\alpha / \beta$ complex and its native receptor (57). Thus, abrogation of the function of these class III region genes can lead to IgAD or hypogammaglobulinemia in mice. Finally, polymorphisms in the TNF- $\alpha$ gene correlate with murine resistance to the development of toxoplasmic encephalitis (63) and influence delayed-type hypersensitivity reactions (64), which suggests that even moderate differences in gene expression can alter immune responsiveness.

In humans, the alleles of TNF- $\alpha$ and LT- $\alpha$ that form part of haplotype 1 are characterized by five nucleotide differences in the exonic, intronic, and proximal promoter regions from other alleles. Polymorphisms for LT- $\beta$ have not yet been described, although the high frequency of polymorphisms in the other genes that comprise haplotype 1 raises the possibility that the genetic composition of the LT- $\beta$ gene may also differ. The promoter for TNF- $\alpha$ in haplotype 1 contains a guanine at position -238 (29) and an adenine at position -308 (65). The LT- $\alpha$ gene has a silent adenine for guanine substitution in exon 1 at position 87, a guanine for adenine substitution in intron 1 that creates an NcoI site, and a substitution of adenine for cytosine at position 800 in exon 2 that results in the replacement of threonine by asparagine (66). The TNF$308 \mathrm{~A}$ polymorphism is associated with enhanced production of both TNF- $\alpha$ and LT- $\alpha(31,67-69)$ and with increased susceptibility to cerebral ma- laria (70), although the mechanisms that underlie the increase in TNF production and the association with disease susceptibility remains unclear (31,71-73). In support of the hypothesis that differences in TNF expression can influence the immune response, recent studies of TNF- $\alpha$ knock-out mice indicate that heterozygous $(+/-)$ mice, which lack one copy of the functional TNF gene, show increased susceptibility to high-dose lipopolysaccharide (LPS) lethality, increased susceptibility to challenge with Candida, and delayed resolution of $C$. parvum-induced inflammation (74). Similar findings have been reported for double TNF/LT- $\alpha$-deficient mice (75). Allelic differences in gene expression could thus result in exposure to elevated concentrations of TNF and LT at critical stages in B cell development that alter the threshold required to initiate the immune response to individual antigens, thereby contributing to the development of IgAD/CVID.

Analysis of the patterns of inheritance of immunodeficiency in this family suggests that IgAD and CVID are not attributable solely to a simple Mendelian trait. In the general population, individuals homozygous for the susceptibility locus are at high risk ( 7 of 54 , or $13 \%$ ) for immunodeficiency. In our family study, the prevalence of immunodeficiency in the S12 family for haplotype 1 heterozygous individuals ( 4 of 41 , or $10 \%$ ) is equivalent to the risk for haplotype 1 homozygous individuals selected at random from the general population $(16,17,33)$. The risk for family members who are homozygous (4 of nine, or $44 \%$ ) is 4 -fold greater than homozygous individuals in the general population or heterozygous family members. This suggests an additive effect of the susceptibility locus. The increased prevalence of disease in family members when compared with members of the general population also suggests that factors in addition to MHC haplotype are contributing to immunodeficiency. Male-to-male transmission of immunodeficiency is well documented in this family, thus a second genetic factor could be transmitted as an autosomal dominant trait that requires the presence of the susceptibility locus on haplotype 1 for development of the disease. Under this scenario, we may identify 6 obligate carriers of a putative second gene not linked to the MHC. Three (S12.II.7, S12.III.20, and S12.III.21) of these potential obligate carriers lack haplotype 1. Two (S12.II.5 and S12.III.12) contain a fragment $(\chi)$ and one (S12.II.4) contains a complete copy of haplotype 1 . All 6 of 
these potential obligate carriers, including those with the susceptibility MHC haplotype, had normal immunoglobulin serum concentrations at the time of evaluation. As an alternative explanation, environmental factors could be the source of the increased risk, a view supported by the fluctuations in serum immunoglobulins observed in affected individuals. The development of disease in different generations would require the environmental factor to be either recurrent or common. Affected family members live within 25 miles of each other, so it is indeed possible that each has been exposed to the same environmental agent. Identification of the MHC gene(s) predisposing to development of the IgAD/CVID spectrum of immunodeficiencies may allow the elucidation of additional genetic or environmental factors.

The 8 blood relatives with subnormal serum immunoglobulin isotype concentrations span the spectrum of immunodeficiency from partial IgA deficiency to complete IgA deficiency to IgA deficiency with IgG subclass deficiencies to CVID. Although not all family members share the identical haplotype by common descent, all affected individuals have inherited at a minimum a fragment of haplotype 1 bounded by the microsatellite markers $821 / 823$ at the class II terminus and HLA-A at the class I terminus. Homozygosity for the 821/823:HLA-A portion of haplotype 1 increased the prevalence of immunodeficiency in family members 4 -fold. A susceptibility locus for IgAD/CVID thus appears to exist within a fragment of the HLA-DR3, -B8, -Al haplotype that contains only 21 known genes. Included within this locus are the genes for TNF- $\alpha$, LT- $\alpha$, and LT- $\beta$, the alteration of which is associated with immunoglobulin deficiencies in mice. It will therefore be of great interest to explore the possibility that altered function of the TNF- $\alpha$ and LT- $\alpha$ genes due to known mutations of the promoter region or as yet undiscovered mutations of LT- $\beta$ increases susceptibility for immunodeficiency in conjunction with other environmental or genetic factors in humans.

\section{Acknowledgments}

We thank the family members in this study for their cooperation, with special thanks to the proband's spouse, who was instrumental in gathering family members for study. We thank Dr. David Chaplin, Washington University, St. Louis, for providing the C4 DNA probe, Dr. J. F. Kau- meyer, Genentech, Inc., South San Francisco, for providing the plasmid Sp64, Dana DePew and Marsha Brand for their help in collecting blood samples and nursing care of family members, and Sarah Robinson for excellent technical assistance.

This work was supported in part by U.S. Public Health Service grants AI07051, AI30879, AI33621, AI34568, AR44505, and RR00032, and by The British Diabetic Association. S. A. N. and R. L. T. are International Research Scholars of the Howard Hughes Medical Institute. M. D. C. is a Howard Hughes Medical Institute Investigator.

The content of this publication does not necessarily reflect the views or policies of the U.S. Department of Health and Human Services, nor does mention of trade names, commercial products, or organizations imply endorsement by the U.S. government.

\section{References}

1. Burrows PD, Cooper MD. (1997) IgA deficiency. Adv. Immunol. 65: 245-276.

2. Rosen FS, Wedgwood RJ, Eibl MM, Fischer A, Aiuti F, Notarangelo L, Kishimoto T, Resnick IB, Hammarstrom L, Seger R, Chapel H, Thompson RA, Cooper MD, Geha RS, Good RA, Waldmann TA. (1997) Primary Immunodeficiency diseases: Report of a WHO scientific group. Clin. Exp. Immunol. 109: S1-S28.

3. Flori NM, Llambi JM, Boren TE, Borja SR, Casariego GF. (1997) Primary immunodeficiency syndrome in Spain: First report of the National Registry in children and adults. J. Clin. Immunol. 17: 333-339.

4. Cooper MD, Lawton AR. (1972) Circulating Bcells in patients with immunodeficiency. Am. J. Pathol. 69: 513-528.

5. Oxelius VA, Laurell AB, Lindquist B, Golebiowska H, Axelsson U, Bjorkander J, Hanson LA. (1981) IgG subclasses in selective IgA deficiency: Importance of $\operatorname{IgG}_{2}-\operatorname{IgA}$ deficiency. N. Engl. J. Med. 304: 1476-1477.

6. French MA, Denis KA, Dawkins R, Peter JB. (1995) Severity of infections in IgA deficiency: Correlation with decreased serum antibodies to pneumococcal polysaccharides and decreased serum $\mathrm{IgG}_{2}$ and/or $\operatorname{IgG}_{4}$. Clin. Exp. Immunol. 100: 47-53.

7. Cunningham Rundles C. (1990) Genetic aspects of immunoglobulin A deficiency. Adv. Hum. Genet. 19: 235-266.

8. Buckley RH. (1975) Clinical and immunologic features of selective IgA deficiency. Birth Defects 11: 134-142.

9. Lawton AR, Royal SA, Self KS, Cooper MD. (1972) IgA determinants on B lymphocytes in 
patients with deficiency of circulating IgA. J. Lab. Clin. Med. 80: 26.

10. Kanoh T, Mizumoto T, Yasuda N, Koya M, Ohno Y, Uchino H, Yoshimura K, Ohkubo Y, Yamaguchi H. (1986) Selective IgA deficiency in Japanese blood donors: Frequency and statistical analysis. Vox Sang. 50: 81-86.

11. Melamed I, Kark JD, Zakuth V, Margalit G, Spirer Z. (1987) Serum immunoglobulin A levels and ethnicity in an Israeli population sample. Clin. Immunol. Immunopathol. 42: 259-264.

12. Oen K, Petty RE, Schroeder ML. (1982) Immunoglobulin A deficiency: Genetic studies. Tissue Antigens 19: 174-182.

13. Grundbacher FJ. (1972) Genetic aspects of selective immunoglobulin A deficiency. J. Med. Genet. 9: 71 .

14. Wollheim FA, Williams RC Jr. (1965) Immunoglobulin studies in six kindreds of patients with adult hypogammaglobulinemia. J. Lab. Clin. Med. 66: 433-445.

15. Schaffer FM, Palermos J, Zhu Z-B, Barger BO, Cooper MD, Volanakis JE. (1989) Individuals with IgA deficiency and common variable immunodeficiency share polymorphisms of major histocompatibility complex class III genes. Proc. Natl. Acad. Sci. U.S.A. 86: 8015-8019.

16. Volanakis JE, Zhu Z-B, Schaffer FM, Macon KJ, Palermos J, Barger BO, Go R, Campbell RD, Schroeder HW Jr, Cooper MD. (1992) Major histocompatibility complex class III genes and susceptibility to immunoglobulin A deficiency and common variable immunodeficiency. J. Clin. Invest. 89: 914-1922.

17. Wilton AN, Cobain TJ, Dawkins RL. (1985) Family studies of IgA deficiency. Immunogenetics 21: 333-342.

18. Olerup O, Smith CI, Hammarstrom L. (1990) Different amino acids at position 57 of the HLA-DQ beta chain associated with susceptibility and resistance to IgA deficiency. Nature 347: 289-290.

19. Ashman RF, Schaffer FM, Kemp JD, Yokoyama WM, Zhu Z-B, Cooper MD, Volanakis JE. (1992) Genetic and immunologic analysis of a family containing five patients with common variable immunodeficiency or selective IgA deficiency. J. Clin. Immunol. 12: 406-412.

20. Cunningham Rundles $C$, Fotino $M$, Rosina O, Peter JB. (1991) Selective IgA deficiency, IgG subclass deficiency, and the major histocompatibility complex. Clin. Immunol. Immunopathol. 61: S61S69.

21. Howe HS, So AKL, Farrant J, Webster ADB. (1991) Common variable immunodeficiency is associated with polymorphic markers in the human major histocompatibility complex. Clin. Exp. Immunol. 83: 387-390.

22. Bucin D, Truedsson L, Hammarstrom L, Smith CI, Sjoholm AG. (1991) C4 polymorphism and major histocompatibility complex haplotypes in IgA de- ficiency: Association with C4A null haplotypes. Exp. Clin. Immunogenet. 8: 233-241.

23. Olerup O, Smith CIE, Bjorkander J, Hammarstrom L. (1992) Shared HLA class II-associated genetic susceptibility and resistance, related to the HLA-DQBl gene, in IgA deficiency and common variable immunodeficiency. Proc. Natl. Acad. Sci. U.S.A. 89: 10653-10657.

24. Campbell RD, Trowsdale J. (1997) A map of the human major histocompatibility complex. Immunol. Today 18: Centerfold.

25. Johnson ML, Keeton LG, Zhu Z-B, Volanakis JE, Cooper MD, Schroeder HW Jr. (1997) Age-related changes in serum immunoglobulins in patients with familial IgA deficiency and common variable immunodeficiency (CVID). Clin. Exp. Immunol. 108: 477-483.

26. Sim E, Cross SJ. (1986) Phenotyping of human complement component C4, a class-III HLA antigen. Biochem. J. 239: 763-767.

27. Udalova IA, Nedospasov SA, Webb GC, Chaplin DD, Turetskaya RL. (1993) Highly informative typing of the human TNF locus using six adjacent polymorphic markers. Genomics 16: 180-186.

28. March RE, Hsieh S-L, Khanna A, Cross SJ, Campbell RD. Application of 10 novel microsatellites mapped in the MHC class III region to the study of susceptibility loci to type I diabetes. In: HLA 1996: Proceedings of the 12th International Histocompatibility Workshop and Conference: EDK. In press.

29. D'Alfonso S, Richiardi PM. (1994) A polymorphic variation in a putative regulation box of the TNFA promoter region. Immunogenetics 39: 150-154.

30. Monos DS, Kamoun M, Udalova IA, Csanky E, Cizman B, Turetskaya RL, Smirnova JB, Zharkov VG, Gasser D, Zmijewski CM, Spielman RS, Nedospasov SA. (1995) Genetic polymorphism of the human tumor necrosis factor region in insulindependent diabetes mellitus: Linkage disequilibrium of TNF $\alpha \beta$ microsatellite alleles with HLA haplotypes. Hum. Immunol. 44: 70-79.

31. Wilson AG, Symons JA, McDowell TL, McDevitt HO, Duff GW. (1997) Effects of a polymorphism in the human tumor necrosis factor alpha promoter on transcriptional activation. Proc. Natl. Acad. Sci. U.S.A. 94: 3195-3199.

32. Jacob CO, Fronek Z, Lewis GD, Koo M, Hansen JA, McDevitt HO. (1990) Heritable major histocompatibility complex class II-associated differences in production of tumor necrosis factor $\alpha$ : Relevance to genetic predisposition to systemic lupus erythematosus. Proc. Natl. Acad. Sci. U.S.A. 87: 1233-1237.

33. Kruskall MS, Marcus-Bagley D, Awdeh Z, Eisenbarth GS, Brink SJ, Katz AJ, Hauser SL, Ahmed AR, Bing DH, Yunis EJ, Schur PH, Alper CA. (1993) Many individuals with the MHC conserved extended [HLA-B8, SC01, DR3] haplotype have immunoglobulin deficiencies. Clin. Res. 41: 277A. 
34. Cudworth AG, Wolf E, Gorsuch AN, Festenstein H. (1979) A new look at HLA genetics with particular reference to type-1 diabetes. Lancet 2: 389391.

35. Miller AP, Rich S, Barbosa J. (1981) Insulin dependent diabetic families: Sex ratio and HLA haplotype segregation. Lancet 1: 388-388.

36. Serjeantson S. (1980) Distorted HLA segregation or biased ascertainment? Lancet 1: 40-41.

37. Vadheim CM, Rotter JI, Maclaren NK, Riley WJ, Anderson CE. (1986) Preferential transmission of diabetic alleles within the HLA gene complex. N. Engl. J. Med. 315: 1314-1318.

38. Awdeh ZL, Raum D, Yunis EJ, Alper CA. (1983) Extended HLA/complement allele haplotypes: Evidence for $\mathrm{T} / \mathrm{t}$-like complex in man. Proc. Natl. Acad. Sci. U.S.A. 80: 259-263.

39. Weitkamp LR. (1979) HLA segregation ratios. Lancet 2: 745-745.

40. Hansen HE, Gurtler H. (1980) Distorted HLA segregation or biased ascertainment? Lancet 1: 41-41.

41. Klitz W, Lo SK, Neugebauer M, Baur MP, Albert ED, Thomson G. (1987) A comprehensive search for segregation distortion in HLA. Hum. Immunol. 18: $163-180$.

42. Conley ME, Cooper MD. (1981) Immature IgA B cells in IgA-deficient patients. N. Engl. J. Med. 305: 495-497.

43. Eibl M, Griscelli C, Seligmann M, Aiuti F, Kishimoto T, Matsmoto S, Hanson LA, Hitzig WH, Thompson RA, Cooper MD, Good RA, Rosen FS, Waldmann TA, Wedgwood RJ. (1988) Primary immunodeficiency diseases. Report of a WHO international workshop. Immunodeficiency Rev. 1: 173-205.

44. Vukmanovic S, Vuckovic S, Stosic-Grujicic S, Ramic Z, Abinun M. (1992) An unusual T-cell surface phenotype in vivo correlates with the failure to proliferate and produce IL- 2 in vitro in a patient with common variable immunodeficiency. Clin. Immunol. Immunopathol. 65: 261-270.

45. Vorechovsky I, Zetterquist H, Paganelli R, Koskinen S, Webster ADB, Björkander J, Smith CI, Hammarstrom L. (1995) Family and linkage study of selective IgA deficiency and common variable immunodeficiency. Clin. Immunol. Immunopathol. 77: 185-192.

46. Clerget-Darpous F, Bonaiti-Pellie C, Hochez J. (1986) Effects of misspecifying genetic parameters in lod score analysis. Biometrics 42: 393-399.

47. Abraham LJ, Leelayuwat C, Grimsley G, DegliEsposti MA, Mann A, Zhang WJ, Christiansen FT, Dawkins RL. (1992) Sequence differences between HLA-B and TNF distinguish different MHC ancestral haplotypes. Tissue Antigens 39: 117-121.

48. Greenberg DA, Doneshka P. (1996) Partitioned association-linkage test: Distinguishing "necessary" from "susceptibility" loci. Genet. Epidemiol. 13: 243-252.

49. Cucca F, Zhu Z-B, Khanna A, Cossu F, Congia M,
Badiali M, Cao A, Arnone M, Piras P, Campbell D, Cooper MD, Volanakis JE, Powis SH. (1998) Evaluation of immunoglobulin A deficiency in Sardinians indicates a susceptibility gene is encoded within the HLA class III region. Clin. Exp. Immunol. 111: 76-80.

50. Congia M, Frau F, Lampis R, Frau R, Mele R, Cucca F, Muntoni F, Porcu S, Boi F, Contu L, La Nasa G, Mulargia M, Pirastu M, Cao A, de Virgiliis S. (1992) A high frequency of the A30, B18, DR3, DRw52, DQw2 extended haplotype in Sardinian celiac disease patients: Further evidence that disease susceptibility is conferred by DQ A1*0501, $\mathrm{Bl}{ }^{* 0201}$. Tissue Antigens 39: 78-83.

51. Liu YJ, Banchereau J. (1996) Mutant mice without B lymphocyte follicles. J. Exp. Med. 184: 12071211.

52. Ware CF, VanArsdale TL, Crowe PD, Browning JL. (1995) The ligands and receptors of the lymphotoxin system. Curr. Top. Microbiol. Immunol. 198: 175-218.

53. Watanabe Y, Jacob CO. (1991) Regulation of MHC class II antigen expression. Opposing effects of tumor necrosis factor- $\alpha$ on IFN- $\gamma$-induced HLA-DR and Ia expression depends on the maturation and differentiation stage of the cell. J. Immunol. 146: 899-905.

54. Browning JL, Ngam-ek A, Lawton $P$, DeMarinis J, Tizard R, Chow EP, Hession C, O'Brine-Greco B, Foley SF, Ware CF. (1993) Lymphotoxin beta, a novel member of the TNF family that forms a heteromeric complex with lymphotoxin on the cell surface. Cell 72: 847-856.

55. Crowe PD, VanArsdale TL, Walter BN, Ware CF, Hession C, Ehrenfels B, Browning JL, Din WF, Goodwin RG, Smith CA. (1994) A lymphotoxinbeta-specific receptor. Science 264: 707-710.

56. De Togni P, Goellner J, Ruddle NH, Streeter PR, Fick A, Mariathasan S, Smith SC, Carlson R, Shornick LP, Strauss-Schoenberger J, Russell JH, Karr R, Chaplin DD. (1994) Abnormal development of peripheral lymphoid organs in mice deficient in lymphotoxin. Science 264: 703-707.

57. Rennert PD, Browning JL, Mebius R, Mackay F, Hochman PS. (1996) Surface lymphotoxin $\alpha / \beta$ complex is required for the development of peripheral lymphoid organs. J. Exp. Med. 184: 19992006.

58. Koni PA, Sacca R, Lawton P, Browning JL, Ruddle $\mathrm{NH}$, Flavell RA. (1997) Distinct roles in lymphoid organogenesis for lymphotoxins $\alpha$ and $\beta$ revealed in lymphotoxin $\beta$-deficient mice. Immunity 6: 491-500.

59. Banks TA, Rouse BT, Kerley MK, Blair PJ, Godfrey VL, Kuklin NA, Bouley DM, Thomas J, Kanangat S, Mucenski ML. (1995) Lymphotoxin- $\alpha$-deficient mice. Effects on secondary lymphoid organ development and humoral immune responsiveness. J. Immunol. 155: 1685-1693.

60. Alimzhanov MB, Kuprash DV, Kosco-Vilbois MH, 
Luz A, Turetskaya RL, Tarakhovsky A, Rajewsky K, Nedospasov SA, Pfeffer K. (1997) Abnormal development of secondary lymphoid tissues in lymphotoxin $\beta$-deficient mice. Proc. Natl. Acad. Sci. U.S.A. 94: 9302-9307.

61. Fu YX, Molina H, Matsumoto M, Huang G, Min J, Chaplin DD. (1997) Lymphotoxin- $\alpha$ (LT $\alpha$ ) supports development of splenic follicular structure that is required for IgG responses. J. Exp. Med. 185: 2111-2120.

62. Pasparakis M, Alexopoulou L, Episkopou V, Kollias G. (1996) Immune and inflammatory responses in TNF- $\alpha$-deficient mice: A crtical requirement for TNF $\alpha$ in the formation of primary B cell follicles, follicular dendritic cell networks and germinal centers, and in the maturation of the immune response. J. Exp. Med. 184: 1397-1411.

63. Freund YR, Sgarlato G, Jacob CO, Suzuki Y, Remington JS. (1992) Polymorphisms in the tumor necrosis factor $\alpha$ (TNF- $\alpha$ ) gene correlate with murine resistance to development of toxoplasmic encephalitis and with levels of TNF- $\alpha$ mRNA in infected brain tissue. J. Exp. Med. 175: 683-688.

64. Muller KM, Lisby S, Arrighi JF, Grau GE, Saurat JH, Hauser C. (1994) H-2D haplotype-linked expression and involvement of TNF- $\alpha$ in Th2 cellmediated tissue inflammation. J. Immunol. 153: 316-324.

65. Wilson AG, de Vries N, Pociot F, di Giovine FS, van der Putte LB, Duff GW. (1993) An allelic polymorphism within the human tumor necrosis factor $\alpha$ promoter region is strongly associated with HLA Al, B8, and DR3 alleles. J. Exp. Med. 177: 557-560.

66. Abraham LJ, Du DC, Zahedi K, Dawkins RL, Whitehead AS. (1991) Haplotypic polymorphisms of the TNFB gene. Immunogenetics 33: 50-53.

67. Bouma G, Crusius JB, Oudkerk Pool M, Kolkman $\mathrm{JJ}$, von Blomberg BM, Kostense PJ, Giphart MJ, Schreuder GM, Meuwissen SG, Pena AS. (1996) Secretion of tumour necrosis factor $\alpha$ and lymphotoxin $\alpha$ in relation to polymorphisms in the TNF genes and HLA-DR alleles: Relevance for inflammatory bowel disease. Scan. J. Immunol. 43: 456-463.

68. Messer G, Spengler U, Jung MC, Honold G,
Blomer K, Pape GR, Riethmuller G, Weiss EH. (1991) Polymorphic structure of the tumor necrosis factor (TNF) locus: An NcoI polymorphism in the first intron of the human TNF- $\beta$ gene correlates with a variant amino acid in position 26 and a reduced level of TNF- $\beta$ production. J. Exp. Med. 173: 209-219.

69. Garcia-Merino A, Alper CA, Usuku K, MarcusBagley D, Lincoln R, Awdeh Z, Yunis EJ, Eisenbarth GS, Brink SJ, Hauser SL. (1996) Tumor necrosis factor (TNF) microsatellite haplotypes in relation to extended haplotypes, susceptibility to diseases associated with the major histocompatibility complex and TNF secretion. Hum. Immunol. 50: 11-21.

70. McGuire W, Hill AV, Allsopp CE, Greenwood BM, Kwiatkowski D. (1994) Variation in the TNF- $\alpha$ promoter region associated with susceptibility to cerebral malaria. Nature 371: 508-510.

71. Jongeneel CV, Beutler B. (1995) Genetic polymorphism in the human TNF region: Correlation or causation? J. Inflam. 46: iii-ivi.

72. Brinkman BM, Zuijdeest D, Kaijzel EL, Breedveld FC, Verweij CL. (1995) Relevance of the tumor necrosis factor alpha (TNF $\alpha)-308$ promoter polymorphism in TNF $\alpha$ gene regulation. J. Inflam. 46: 32-41.

73. Stuber F, Udalova IA, Book M, Drutskaya LN, Kuprash DV, Turetskaya RL, Schade FU, Nedospasov SA. (1995) - 308 tumor necrosis factor (TNF) polymorphism is not associated with survival in severe sepsis and is unrelated to lipopolysaccharide inducibility of the human TNF promoter. J. Inflam. 46: 42-50.

74. Marino MW, Dunn A, Grail D, Inglese $M$, Noguchi Y, Richards E, Jungbluth A, Wada H, Moore M, Williamson B, Basu S, Old LJ. (1997) Characterization of tumor necrosis factor-deficient mice. Proc. Natl. Acad. Sci. U.S.A. 94: 8093-8098.

75. Amiot F, Boussadia O, Cases S, Fitting C, Lebastard M, Cavaillon JM, Milon G, Dautry F. (1997) Mice heterozygous for a deletion of the tumor necrosis factor- $\alpha$ and lymphotoxin- $\alpha$ genes: Biological importance of a nonlinear response of tumor necrosis factor- $\alpha$ to gene dosage. Eur. J. Immunol. 27: 1035-1042. 